\title{
The EEAS and the challenges of multilateral diplomacy
}

\author{
Knud Erik Jørgensen \\ Jean Monnet Professor of Political Science \\ Department of Political Science \\ Aarhus University
}

\begin{abstract}
Summary: I. Introduction.-II. Conducting multilateral diplomacy underpinned by bilateral relations and unilateral action.-III. Bridging Form and Content. -IV. Outreach, Coordination and Delegation. - V. A Differentiated Approach.-VI. Reforming International Institutions. - VII. Improving EU Performance: effective multilateralism abroad and at home.VIII. Welcoming a Politics of European Multilateral Diplomacy.-IX. The Domestic Dimension of Multilateral Diplomacy. - X. Leadership and Negotiation Style.-XI. Abandoning Multilateralism as Political Ideology.XII. Conclusion and Perspectives.
\end{abstract}

Resumen: El artículo se centra en el análisis de los desafíos más importantes que la UE ha de afrontar en el ámbito de la diplomacia multilateral, tras las importantes innovaciones institucionales contenidas en el Tratado de Lisboa, y específicamente tras la creación del SEAE. De manera más precisa, se identifican y discuten críticamente diez grandes desafíos en este terreno, así como su posible relación con las dimensiones instrumentales del nuevo SEAE, y de las diversas instituciones multilaterales respectivamente. El artículo sugiere que el despliegue de las singulares dimensiones formales e institucionales del mismo se verá en cierto modo empequeñecido, al menos a corto y medio plazo, por la necesidad de responder a las prioridades de una agenda política llena de desafíos.

Palabras clave: UE, SEAE, multilateralismo, diplomacia, política exterior.

Abstract: This article focuses on some important challenges in the field of multilateral diplomacy that the EU has to confront after the prominent institutional innovations included in the Treaty of Lisbon, and particularly, the creation of the EEAS. More specifically, ten main challenges arte briefly outlined and critically examined. Moreover, the article focuses deliberately on the instrumental dimensions of the EEAS and multilateral institutions, respectively. This implies that the (unique) legal-institutional features will be downplayed in exchange of a strong focus on the political tasks that will keep the EEAS busy for the foreseeable future.

Keywords: EU, EEAS, multilateralism, diplomacy, foreign policy. 


\section{Introduction}

EEAS diplomats face startling challenges. Not only are they about to build the foreign service of a world player, in addition research concludes more frequently than not that the EU's multilateral diplomacy experiences severe problems. A CEPS report concludes that for the EU, the state of affairs in many international institutions is 'not satisfactory'. ${ }^{1}$ While 'satisfactory' is open for discussion, the finding is nothing else but alarming. Moreover, some observers point out that within the (high priority) field of human rights the EU's influence has been decreasing for more than a decade. ${ }^{2}$ Similarly, others claim that the liberal internationalist strategy pursued by the EU is becoming increasingly irrelevant. ${ }^{3}$ A comparative study of the EU's performance within international institutions concludes that in most of the analyzed cases, performance is in severe need of improvement. ${ }^{4}$ In some cases, e.g. concerning NATO, it is difficult simply to find out what Europeans want. ${ }^{5}$

Multilateral institutions can be regarded as both means and ends. They can be regarded as manifestations of international cooperation and, thus, as the antithesis to international conflict. As such, they can be seen as ends, to be cherished in their own right. However, multilateral institutions can also be seen as agents, equipped with mandates to serve specified functions. Or, put differently, as instruments to be used in order to achieve political and diplomatic objectives.

For those involved in constructing the EEAS, the result represents a final accomplishment. It is an end, an example of institutional reform and effective multilateralism at home. ${ }^{6}$ The process of creating the EEAS can be

1 Vid. EMERSON, M. and KACYINSKI, P.M., "Looking afresh at the external representation of the EU in the international arena, post-Lisbon" in CEPS Policy Brief, $\mathrm{n}^{\circ} 212$, Brussels, July 2010.

2 Vid. GOWAN, R. and BRANDTNER, F., "The EU and Human Rights at the UN: 2010 Review" in European Council for Foreign Relations Papers, 2010.

3 Vid. HAINE, J.Y. "The European Crisis of Liberal Internationalism" in International Journal, 2009, pp. 453-479.

4 Vid. JØRGENSEN, K.E., OBERTHÜR, S. and SHAHIN, J. (eds.), "Special Issue on the Performance of the EU in International Institutions" in Journal of European Integration, vol. 32(6), 2011, forthcoming. Vid. also LAATIKAINEN, K. and SMITH, K.E. (eds.), Intersecting Multilateralisms: The European Union at the United Nations, Palgrave, Basingstoke, 2006.

5 Vid. VASCONCELOS, A. (ed.), "What do Europeans want from NATO?", Institute for Security Studies Report, $\mathrm{n}^{\circ}$ 8, 2010. Document available at http://www.iss.europa.eu/uploads/ media/Report_8-What_do_Europeans_want_from_NATO.pdf

6 Vid. RIJKS, D. and WHITMAN, R. (2007), "European Diplomatic Representations in Third Countries: Trends and Options" in GRAHAM, A. and MISSIROLI, A. (eds.), The EU Foreign Service: how to build a more effective common policy, European Policy Centre 
seen as a case of institutional design and the difficult negotiations throughout 2010 demonstrate that the EEAS did not come easy. ${ }^{7}$ For those who are going to use the EEAS, for instance in the conduct of multilateral diplomacy, the service will foremost be a means to use in order to achieve changing political objectives.

The EU's multilateral diplomacy is very extensive and the challenges most demanding. In order to describe the challenges the emerging EEAS is facing, it is necessary first to specify the sectors of multilateral diplomacy that the EEAS is responsible for. It is well-known that member states organize their foreign affairs differently. ${ }^{8}$ In some member states, e.g. Denmark and Sweden, the ministries of foreign affairs are not only responsible for foreign policy per se, but also for trade and development policy. In other member states, for instance in Germany and the United Kingdom, trade and development issues are organized in separate ministries. The EU has chosen the latter model, i.e. kept separate DGs for trade and development policies, indeed the issue of how to cut the cake, i.e., the organization of foreign affairs has been somewhat politicized.

This article focuses on ten important challenges in the field of multilateral diplomacy. Each challenge is briefly outlined and critically examined. Moreover, the article focuses deliberately on the instrumental dimensions of the EEAS and multilateral institutions, respectively. This implies that the (unique) legal-institutional features will be downplayed in exchange of a strong focus on the political tasks that will keep the EEAS busy for the foreseeable future.

\section{Conducting multilateral diplomacy underpinned by bilateral relations and unilateral action}

The EEAS organigram (see Appendix) shows that the new foreign service is meant to cultivate both bilateral and multilateral relations. While perhaps not presented in such a neat fashion before, this dual track is a continuation of previous practice. In the conduct of its foreign policy, the European Union (EU) has always used several types of foreign policy strategy: unilat-

Working Paper $n^{\circ}$ 28, Brussels; and DUKE, S., "Providing for European-Level Diplomacy after Lisbon: The Case of the European External Action Service" in The Hague Journal of Diplomacy, vol. 4, 2009, pp. 211-233.

7 Vid. VANHOONACKER, S. and RESLOW, N., "The European Eternal Action Service: Living Forwards by Understanding Backwards" in European Foreign Affairs Review, vol. 15, 2010, pp. 1-18.

${ }^{8}$ Vid. HOCKING, B. and SPENCE, D., (eds.), Foreign Ministries in the European Union, Palgrave, London, 2002. 
eral, bilateral and multilateral. The two former strategies might not appear as officially recognized or publicized as the latter, yet de facto they have been part of the strategy portfolio for a long time.

The three strategies are not necessarily mutually exclusive. Political objectives, pursued by means of multilateral strategies, are often difficult to achieve when they are not underpinned by active cultivation of bilateral relations or, at times, unilateral action. Unilateral action can provide the necessary conditions for a major breakthrough in otherwise stalled multilateral negotiations and bilateral relations sometimes function as the innovative or dynamic undergrowth, providing the leadership, coalition-building processes, minilateralism and general preparatory work that might secure an agreement within multilateral diplomacy, often characterized by a large number of participants.

In order to understand multilateral outcomes, minilateralism has frequently proved important. Minilateralism is the label we attach to international agreements that are reached by a select sub-grouping of a larger multilateral organization or regime and subsequently adopted by other states. Hence, minilateralism is characterized by an exclusive group of k-states, i.e., key states within a specific issue area, reaching an agreement which subsequently is accepted within a larger multilateral setting. One example is the policy by France and the United Kingdom vis-à-vis the break-up of former Yugoslavia, a policy that was accepted by partners within the European Union, and subsequently adopted by the UN Security Council. A second example of minilateralism is the EU-3 talks with Iran on nuclear issues, also characterized by three levels of handling an issue: the exclusive k-group, the EU and the UN Security Council.

Minilateralism should not be conflated with plurilateral agreements being concluded by a small select grouping of states and subsequently adhered to by a larger segment of international society. A reference to the plurilateral instrument was made after the 2003 WTO Doha-Round meltdown in Cancun, when the European Union suggested that given the multilateral deadlock, perhaps a plurilateral approach would be a desirable or at least a possible alternative. Similarly, non-proliferation regimes are characterized by an exclusive membership yet a very wide grouping of adherents.

The swift fashion in which the deadlocked multilateral Doha-round has been replaced by bilateral trade agreements demonstrate that DG Trade and the Commission in general is capable of employing available strategies and change from one to the other when deemed necessary. The EEAS, being directed buy a former Trade Commissioner, might have this insight in its 'lessons learned' files. In short, successful multilateral negotiations depend crucially on a rich undergrowth of bilateral relations, engagements in relevant $\mathrm{k}$-groups and occasional unilateral action. 


\section{Bridging Form and Content}

The EEAS has been created by the Treaty of Lisbon, or, rather by the drafters of the treaty and its key interpreters, i.e., the inter-institutional mingling that took place throughout 2010. In this fashion the EEAS has a legal footing. However, the success of the EU's multilateral diplomacy will be termined by capable politics and flexible interpretation of rules and principles. The age-old distinction between form and content is highly relevant for the EU's international performance. The problem is that the EU tends to prioritise form over content and its own institutional logic over external context. One example concerns the highly developed legalistic culture in which EU institutions are embedded, as demonstrated when the EU declares that its strategy towards Russia has 'expired'. Most strategists would be greatly surprised to learn that strategies can 'expire'. It thus seems we have somehow become prisoners of Europe's grand strategy objective of legalizing international politics. A second example concerns the fabulous mathematics of formal representation. Concerning EU representation in multilateral institutions, it is tempting to focus on legal arrangements and institutional design. Indeed there are excellent studies on both aspects. However, the EEAS should probably not go too far in the direction of formal representation, especially because it will end up being an 'accountant', i.e. obsessed with counting or recalculating seats or votes, disregarding that this is just one of several aspects. Third, given the 'generous' interpretation of 'strategic' and the derived proliferation of strategic partners, one may wonder if the EU eventually ends up having 192 strategic partners.

\section{Outreach, Coordination and Delegation}

Research shows fairly consistently that European diplomats are hard working, yet spend most of their time on internal coordination, leaving limited time for outreach activities. For the EEAS, it will therefore be a considerable task to change the balance between coordination and outreach activities.

The point of departure is that the EU is deeply marked by its dual nature, being both an international subsystem in its own right and an actor within the wider international system. Whereas coordination of EU member states positions counts as diplomacy in the international subsystem, it counts somehow differently when the EU acts as an international actor. Then it either counts as a regional level game of classical diplomacy or it counts as EU-domestic politics that happens to be conducted 
by diplomats. ${ }^{9}$ Thus, while coordination is a precondition for a union of states, the organization of coordination and delegation is in severe need of creative thinking.

In the present context, outreach should be understood as interaction with third party diplomats, acts of persuasion or coercion, taking initiatives, seeking influence or providing leadership. Concerning all these issues, the probably most significant feature is that correlation between degree of coordination and outreach or impact does not show a consistent pattern. In literally all policy fields, i.e., spanning environment, trade, UNGA politics, security, development, value promotion, and health, is it possible to identify issue areas in which the degree of EU coordination is fairly high, yet despite this constant, the degree of outreach varies significantly.

Outreach has been fairly high within the following issue areas: climate, trade (WTO), and international justice (ICC). Concerning the WTO case the EU, being a co-designer and co-creator of the WTO, demonstrates several attempts at agenda setting. Furthermore, the case shows the EU's flexible approach to international trade policy: if multilateral strategies do not work, the EU does not refrain from using bilateral strategies. The EPAs being negotiated between the EU and ACP countries can be seen as a junction between development and trade policy and also a border case between bilateral and multilateral strategy. In any case, coordination and outreach has been high.

Moreover, it is easy to identify issue areas, in which coordination is remarkably high and outreach fairly low. Examples include as diverse areas as the non-proliferation regimes, UNGA politics and human rights promotion. In these cases, it seems that coordination is so demanding in terms of manpower and time that not much has been left to interact with third parties. The case of the Human Rights Council (HRC) shows that the EU attempted to create a new institution that would leave the vices of the former Commission on $\mathrm{Hu}-$ man Rights (CHR) behind, yet experienced fierce opposition to membership criteria and subsequently decided that the HRC would be better than no institution. Since the HRC was founded, the EU has experienced the consequences of that decision, including the experience of being outvoted fairly consistently.

Despite EU member states stating their commitment to a strengthened role within the two major international financial institutions, the cases of the IMF and the World Bank remain important examples of meagre efforts at coordination and outreach. The introduction of the Euro and the European Central Bank seems not to have significantly changed this situation ${ }^{10}$

9 Vid. on this, JøRGENSEN, K.E. (ed.), The European Union and International Organizations, Taylor \& Francis, London, 2009

10 Vid. BINI-SMAGHI, L., “A Single EU Seat in the IMF?” in JØRGENSEN, K.E. (ed.), The European Union and International Organizations, op. cit., note 9, pp. 61-79. 
(Bini-Smaghi 2009). Also coordination within NATO has traditionally been modest. The case of NATO is in several ways fairly special, in part because the US enjoys a primus inter pares status, in part because more than a handful EU member states are not NATO members. This makes a common EU position somewhat awkward but a caucus of EU member states that are also members of NATO could be seen as a pre-condition for EU strategic action in the field of defence. Neither the end of the Cold War, nor the dissolution of the Soviet Union has changed this. EU member states seem to enjoy the luxury of resisting both enhanced coordination and a change to supervised delegation.

Paradoxically, a high degree of outreach does not necessarily require a high degree of coordination but then we are beyond the confines of common outreach. Perhaps the proceedings at the Rome Conference, creating the ICC, constitute the prime example of this counter intuitive combination. Without prior coordination, EU member states simply happened to agree on the basic principles of what is now known as the ICC. Subsequently, acknowledging this accidental consensus, support of the ICC became an aspect of the EU's international identity and coordination efforts were enhanced. The European position changed from accidental to precious, not least when under attack from abroad.

\section{A Differentiated Approach}

Despite belonging to the same category, international organizations are not like units. They have highly different governance structures and memberships. This pronounced diversity explains why one size does not fit all and why the EEAS faces a challenge in terms of figuring out the suitable approach to individual multilateral institutions.

Moreover, multilateral institutions have (primarily) states as members and therefore need these states to engage in some political gardening to keep the institutions on track and on mission. Hence, the foreign policy of states requires a multilateral dimension. Multilateral foreign policy strategies prioritize the promotion of and commitment to international institutions, including the resources it takes to cultivate multilateral institutions. The United States opted for this strategy after the end of WW2 and immediately after the end of the Cold War. At other times, the commitment to multilateral institutions has been more ambivalent. ${ }^{11}$

11 Vid. PATRICK, S. and FORMAN, S. (eds.), Multilateralism and US Foreign Policy: Ambivalent Engagement, Lynne Rienner, Boulder, 2002. 
One of the stated strategic objectives of European foreign policy is to promote effective multilateralism. Whereas (other) great powers have been more reluctant or simply incapable of shaping the multilateral system or its individual institutions - Russia, China, India and Japan have had a modest impact on the system - middle powers such as Canada and the Nordic states have traditionally been keen supporters of multilateralism. Given that the future of the multilateral system partly depends on an increased sense of ownership among emerging powers, it will be a huge task for the European Union and its allies to persuade emerging powers to multilateral commitments. $^{12}$

\section{Reforming International Institutions}

Given the EU's declared foreign policy objective of 'effective multilateralism', the EEAS is bound to engage in reforming multilateral institutions. Most international institutions are creations of the $20^{\text {th }}$ century and therefore not necessarily suitable for the challenges of the $21^{\text {st }}$ century. Several of the important multilateral institutions were created during the Cold War and, as the world has subsequently changed, they are in severe need of more or less comprehensive reform. Two observers put it rather brutally, "The system of international institutions that the United States and its allies built after World War II and steadily expanded over the course of the Cold War is broken". ${ }^{13}$ Moreover, international institutions are characterized by an ever more present negative trade-off between inclusion, legitimacy and effectiveness. As the number of participant state members increases, so does the number of veto-players. At the same time, there is an increasing imbalance between the provision of leadership, which is fatally lacking, and an ever-broader portfolio of global demands and tasks to handle. It does not help that several key states pay lip service to their obligations towards international institutions or act as custodians insisting on yesterday's arrangements. In short, multilateral institutions are characterized by an ever wider expectation-political investment gap triggering, in turn, frustration, apathy or cynicism concerning the absence of expected deliverables.

Examples of this crisis abound, ranging from the stalled UN reform process, via the dire straits of the Non-Proliferation Treaty regime to the

12 Ibid.

13 Vid. IKENBERRY, J.G. and SLAUGHTER, A.M., Forging a World of Liberty Under Law. U.S. National Security in the $21^{\text {st }}$ Century, Princeton University Press, Princeton, 2006, p. 7. In this work the authors outline a hugely ambitions plan to reform and partly refound existing international institutions to suit present times. 
deadlocked WTO Doha-round and the never-ending COP-n process. It is clear that the crisis requires some exquisite intellectual innovative thinking, strong political leadership and a dash of pure luck to flesh out sustainable solutions. The contemporary crisis of multilateralism appears to be more profound than previous crises and it seems to have several sources. ${ }^{14}$

The need for reform is potentially good news for the EU because if the Union genuinely aims at an enhanced representation in these organizations, it appears to be easier to achieve when the institutions are bound to change. Yet it is also bad news, in part because international organizations are notoriously difficult to reform, in part because other players might prefer to change the international institutions in directions that are more or less incompatible with the present international liberal order. Hence, European policy-makers face difficult dilemmas.

One option would be a long march through international institutional reform, a march characterized by numerous veto players and a limited record of successful reforms. In this context, the challenge of setting the acceptance bar has proven to be an important issue. Two examples suffice to illustrate the point. Given that the EU templates for the HRC were rejected by a majority of UN member states, the EU settled for the second best, i.e. the achievable solution. Third, having in the European Security Strategy listed support of the UN among top foreign policy objectives, it is only natural for the EU to try to become involved in UNSC reform, yet it was quickly realized that many obstacles were in the way for the EU to take such a role. When it comes to human rights institutions, it was in international society increasingly acknowledged that the CHR was less than efficient in promoting human rights. In the context of wider UN reform, a substitute institution was therefore sought after. The EU engaged in this aspect of institutional reform and was successful in terms of actually being a co-founder of a new institution yet largely unsuccessful in terms of getting EU positions adopted. It remains to be seen whether the HRC will be an effective multilateral institution in terms of promoting human rights. The case of reforming FAO also shows that the EU at times is ready to settle for less than the full portfolio of EU preferences.

A second option would be to initiate new international institutions in which the EU is represented as the union prefers to be represented. There are some examples of the EU being engaged in shaping institutionalization and/or institutional reform. The institutionalization of the GATT becoming the WTO and the CSCE becoming OSCE are two examples. Also the more recent crea-

14 This is acknowledged by senior observers such as BRZEZINSKI, Z. and SCOWCROFT, B., in America and the World, Basic Books, New York, 2008. 
tion of the UN Peace Building Commission can be seen as an example as can the recent emergence of G20. The examples show that this option is not necessarily wishful thinking. On the other hand, the EU has not been deeply engaged in ongoing attempts to reform the international financial institutions (the IMF and the World Bank), the prime defence organization in Europe (NATO), or the backbone of international non-proliferation policy (NPT). Hence, the EU's impact on these larger or smaller reforms has been marginal.

\section{Improving EU Performance: effective multilateralism abroad and at home}

The EU's objective of 'effective multilateralism' concerns the functioning of international institutions, yet it can be turned upside down. It can, thus, become an objective concerning the EU's own performance in international organizations - effective multilateralism at home. If the EEAS chooses to engage in such a task, it might find some inspiration in studies of organizational performance, specifically the four main elements that constitute performance.

In order to improve effectiveness, i.e., the degree to which stated objectives are achieved, the EEAS would need to spend some time on clarifying what exactly the EU's objectives are. As a recent publication asks, "what do Europeans want from NATO?". ${ }^{15}$ In fact, such questions are most relevant for all international institutions in which the EU aims at playing a role. Somewhat surprisingly, analysts often have a hard time simply identifying the EU's objectives. Obviously, a much more important reason to explicitly state European objectives is that it would leave no doubt among third-states or European public audiences about the means and ends in European multilateral diplomacy.

Efficiency concerns the costs, relative to other organizations, of achieving stated objectives. While the EEAS itself might be run in a cost-efficient manner, European diplomacy at large remains the probably most expensive diplomatic service in the world, employing more than twice the number of American diplomats. Up to 28 diplomatic services operate simultaneously yet at times out of sync or working in different directions. Without encroaching on national priorities, the EEAS might consider ways to change the European tradition for relatively low levels of cost efficiency. In times of severe budget constraints, ministries of finance might even push in the direction of more functional and cost-efficient arrangements.

15 Vid. VASCOCELOS, A., op. cit., note 5. 
The relevance of the EEAS, perceived by key stakeholders such as EU member states, should not be taken for granted. These key stakeholders are increasingly squeezed between efficiency and symbolic politics, i.e. the power, pride and prestige of being represented in international organizations. Two European seats less at the IMF board, too many European members of the G20, generally over-represented and underperforming. In international media, such headlines pop up more and more frequently, implying that the current double representation might become a feature of the past. Other stakeholders wish the EEAS success, provided it delivers according to the objectives of their wish-list. ${ }^{16}$

Concerning financial viability, the challenge for the EEAS is to secure a suitable balance between tasks given and the provision of financial resources. If the current Zeitgeist is pleading for both downsizing budgets and increasing global aspirations, it is quite predictable that a gap will emerge between supply and demand and financial viability would be at risk.

\section{Welcoming a Politics of European Multilateral Diplomacy}

The EEAS, being an instrument, faces the challenge of finding suitable sponsors for its policies. Any European foreign policy, worthy of the name, will be determined by the outcome of the politics of European foreign policy, i.e. societal groupings cultivating their specific and often contending ideas about means and ends of foreign policy. These groupings comprise political parties, NGOs, media, and commercial interests (cf. European shipping companies having a direct interest in operation Atalanta). NGOs working on development issues are illustrative of this dynamic. They might at times be highly critical of European development policy and programmes but might be turned into one of the push-factors of policy-making within the field.

The politics of European multilateral diplomacy will not be without problems, especially because not all political forces are friends of multilateral diplomacy. Ole Holsti and James Rosenau, ${ }^{17}$ make a useful distinction between different elite attitudes towards foreign policy. Though their conceptualization has been developed to analyze American foreign policy, it seems highly applicable to the European political landscape, cf. Figure 1.

16 Vid. GAVAS, M. and MAXWELL, S., "Indicators of a successful EEAS" in European Development Cooperation Strengthening Programme, Overseas Development Institute, London, 2010.

17 Vid. HOLSTI, O.R. and ROSEANU, J.N. "The Structure of Foreign Policy Attitudes among American Leaders" in The Journal of Politics, Vol. 52, $\mathrm{n}^{\circ}$ 1, 1990, pp. 94-125. 
Cooperative Internationalism

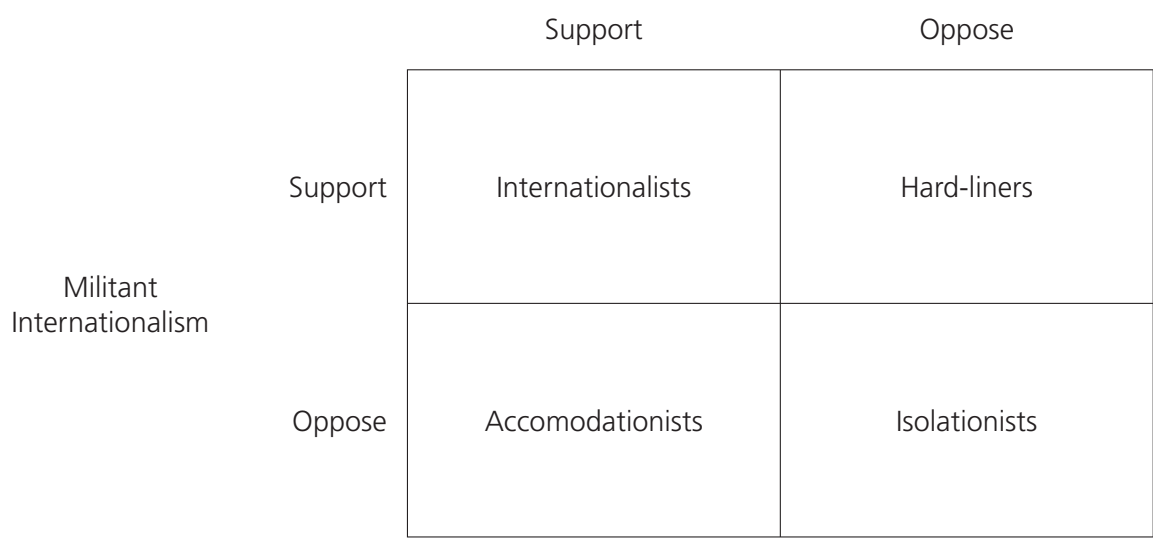

Figure 1

Elite attitudes to foreign policy.

Based on Ole R. Holsti and James N. Rosenau (1990)

The figure demonstrates that only two out of four categories of elite attitudes favour multilateral action, the difference between them being determined by attitudes towards the employment of military means - an issue not unfamiliar in European politics. Hence, the cultivation of multilateral diplomacy by EEAS diplomats is likely to be appreciated by 'internationalists' and 'accomodationists', yet it is bound to be strongly criticized by 'hard liners' and 'isolationists'. The EEAS (and the making of European foreign policy generally) represents, though unevenly, such foreign policy traditions.

According to the latter two foreign policy traditions, multilateral approaches are synonymous with inaction, unwarranted constraints on foreign policy or both. Hence, it would be irresponsible to leave decisions concerning crucial issues to multilateral institutions. If states (or other players) nevertheless opt for multilateralism, they should use multilateral institutions instrumentally thereby letting multilateral agreements function as windowdressing. Powerful players should not constrain themselves by means of being embedded in a web of rules and obligations. A third argument, often applied by opponents of European integration, is that small states should not give up the formal and symbolic dimensions of independence or autonomous decision-making power.

Trans-national actors (TNAs) play an increasingly significant role in the contemporary multilateral system. TNAs frequently contribute to agendasetting, sometimes provide intellectual leadership, push for some interna- 
tional agreements and campaign against other agreements. Prominent examples include the creation of the International Criminal Court and the international treaty banning landmines, both initiatives being sponsored by the European Union and NGOs working in the field of human rights. The enduring significance of TNAs remains an empirical question, yet it is beyond discussion that they increasingly contribute to the politics of multilateralism, despite not being formal members.

If the EEAS develops without such interfaces to a politics of European foreign policy, it is likely it will become a bureaucratic-diplomatic institution of limited consequence.

\section{The Domestic Dimension of Multilateral Diplomacy}

Studies of American policy towards multilateral institutions conclude rather consistently that domestic politics is the single most important factor when explaining the dynamics of American multilateral diplomacy. ${ }^{18}$ While such conclusions might not apply to the European case, the domestic dimension of multilateral diplomacy represents in any case a challenge because domestic actors have vested interests in the outcome of multilateral diplomacy, either pleading in favour of certain solutions or perhaps fearing the worst and therefore pleading for protection. The EEAS will frequently find itself in two-level games of negotiation, addressing both domestic audiances and international negotiation partners.

We can therefore ask when European diplomats try to protect European constituencies from the effects of international agreements and when they aim at projecting European solutions to global problems. Concerning environmental standards, European values, human rights and governance models, projection seems to be the predominant answer. Most of these areas are characterized by vocal and/or influential special interest groups who have played a more or less significant role in taking policy-making international. In general, when there is a domestic dimension to multilateral diplomacy, the nature of the diplomatic game changes. It becomes a two or three level game each characterized by specific constraints and opportunities. ${ }^{19}$

This leads us to a second major aspect of the domestic dimension to multilateral diplomacy, namely the domestic dimension providing the op-

18 Vid. KARNS, M. and MINGST, K. (eds.), The United States and Multilateral Institutions: Patterns of Changing Instrumentality and Influence, Ohio State University Press, Columbus, 1990.

19 Vid. PUTNAM, R.D. et al. (ed.), Double-Edged Diplomacy: International Bargaining and Domestic Politics, University of California Press, Berkeley, 1993. 
portunity of structural leadership in multilateral diplomacy. A few examples suffice to illustrate the argument. First, the effectiveness of the NPT and associated export control regimes clearly hinges on compliance. Hence, it makes a difference for the EU that implementation of commitments and obligations are handled swiftly throughout the EU by means of directives. Second, though outside the EEAS fields of responsibility, CAP reforms since the early 1990s are frequently explained by the fact that each domestic reform strengthened the EU's negotiation position in the context of first GATT and subsequently WTO negotiations. ${ }^{20}$

\section{Leadership and Negotiation Style}

It is often claimed that the EU is best at grey committee work behind closed doors and, thus, outside the spotlight of international media, focusing on spectacular breaking news. However, the world of multilateral institutions is generally, perhaps contrary to expectations, far from an ideal environment for the EU, the prime reason being that multilateral diplomacy is strongly state-centric, invites to frequent tactical manoeuvring and requires profound coordination among EU member states. After all, international governmental organizations have been created by states and have states as members, whereas international regimes have states as contracting parties, being therefore also key interpreters of agreements and contracts.

In order to differentiate among different kinds of negotiations styles, it is helpful to use the distinction between a supervised delegation model and a coordination model again, this time paired with a distinction between reactive and proactive diplomacy.

EU environmental diplomacy was for a long time characterized by reactive, coordinated policy-making. The European Commission was preoccupied with gaining both internal and external recognition and the EC foremost responded to environmental challenges. ${ }^{21} \mathrm{~A}$ similar process from

${ }^{20}$ For more on these issues Vid. DÜR, A. and ZIMMERMANN, H., "Introduction: The EU in International Trade Negotiations" in Journal of Common Market Studies, vol. 45(4), 2007. pp. 771-787; YOUNG, A.R., "Trade Politics Ain't What It Used to Be: The European Union in the Doha Round" in Journal of Common Market Studies, vol. 45(5), 2007, 789-811; and MORTENSEN, J.L., "The World Trade Organization and the European Union" in JÖRGENSEN, K.E., op. cit., note 9, pp. 80-100.

${ }^{21}$ On the EU's global environmental policy Vid. FALKNER, R., "The political economy of 'normative power' Europe: EU environmental leadership in international biotechnology regulation" in Journal of European Public Policy, vol. 14(4), 2007, pp. 507-526; and OBERTHÜR, S. and KELLY, C.R., "EU Leadership in International Climate Policy: Achievements and Challenges" in The International Spectator, vol. 43(3), 2008, pp. 35-50. 
reactive to proactive characterizes the trade policy field, in which the EC was a formidable reactive player for years, actually during most of the GATT's existence. With the creation of the WTO, this style changed profoundly. Whereas the use of the supervised delegation model has remained a constant, the EU in the first place contributed to the institutional design of the WTO, in which the European Commission is a member in its own right. The EU became a perfect match to the second trade superpower, the US. Furthermore, the EU has gone proactive in the sense of trying to set the agenda, even with some success as the Doha Round enterprise is based on some EU templates for world trade. Yet, the EU has also experienced that putting the Singapore issues on the agenda has provoked quite some opposition and currently they are off the agenda again. This process suggests that the aspiring world trade leader somehow lacks followers. Finally, one can argue that also the EU's development policy has changed from a reactive to a proactive mode. The row of Lomé Conventions signals strong path dependencies, whereas the Cotonou agreements signal discontinuity and a new start of a long-time relationship with developing countries. Perhaps the novel enterprise of negotiating EPAs first and foremost demonstrates that shows of force may backfire. ${ }^{22}$ Put differently, the assignment of trade negotiations to DG Trade resulted in highly asymmetrical negotiations, in which DG Trade diplomats played the hard ball politics they are used to from negotiations with the US, China and other world traders. Diplomats from ACP countries were less than a perfect match and after some time they went into a "resist by all means" approach. The fact that the UK intervened in the process by publicly and effectively "unsigning" the mandate to EU negotiators, contributes to the messy EPA process. In the context of EPAs, it is also significant that the previous agreements with ACP countries were reached by means of big- $\mathrm{N}$ multilateral fora, whereas the EPAs are characterized by negotiations in rather small- $\mathrm{N}$ fora.

Reactive diplomacy based on a coordination mode of governance characterizes negotiation styles in a wide set of policy fields. IMF macro-economics is representative in the sense that EU member states primarily respond to initiatives coming from other corners of the world. To the degree they try to coordinate positions, this coordination is effectively blocked by the governance structure of the IMF according to which EU member states belong to several different constituencies in which they sometimes are in a minority position. ${ }^{23}$ In contrast to the field of international finance, the EU coordinates really hard

22 Vid. ELGSTRÖM, O., "The European Union as a Leader in International Multilateral Negotiations: A Problematic Aspiration?” in International Relations, vol. 21(4), 2007, pp. 445-458.

${ }^{23}$ In this vein, Vid. PISANI-FERRY, J., "The Accidental Player: The EU and the Global Economy” in JÖRGENSEN, K.E., op. cit., note 9, pp. 21-36. 
prior to the NPT Review Conferences. Before the 2005 NPT Review Conference the EU managed to formulate a consensus position and given the EUs own configuration of both Nuclear Weapon States (NWS) and non-NWS, the consensus agreement had a fair chance to be adopted as the conference conclusion. However, despite the common position and the time and manpower consuming activities it took to hammer out the EU's Common Position, the European NWS - France and Great Britain - abandoned the common position and started pleading for rolling back previous NPT achievements, especially stated commitments to disarmament. ${ }^{24}$

Finally, we can turn to a proactive style based on coordination. Despite being characterized by some variation, diplomacy in UNGA Committees displays some of the coordination dynamics. In many ways the degree of prior coordination is impressive concerning its effectiveness and degree of consistency. The high percentage of consensus voting by EU member states raises some serious doubt about one of the default explanations of EU foreign policy making: "due to different national interests...", or, "due to different historical traditions...". In the HRC, the EU is actually speaking with one voice, yet finding itself in a minority position and, therefore, unable to persuade most "sving states" to subscribe to EU positions. ${ }^{25}$ Hence, in this case the intuitively strong explanation of limited influence - internal disagreement among EU member states - is irrelevant. The rather common analytical practice of considering lack of consensus a default mode explanation is in this case less than helpful. The existing literature on the topic does not allow us to conclude whether the EU's diplomatic skills in entrepreneurial leadership have been fully exploited, i.e. the degree to which the EU has tried to form alliances and seeking alignment with like-minded countries. It is similarly difficult to know if the option of issue-linkage has been explored. In summary, the prime downside of thorough coordination seems to be that European diplomats spend so much time on internal coordination that they have limited time to interact with third party states, seeking alignments, engaging in persuasion, exploring potential issue linkages. Finally, the cumbersome process of common interest-formation makes the EU a fairly inflexible negotiator.

${ }^{24}$ On the EU's role in the non-proliferation agenda Vid. SCHMIT, B. (ed.), "Effective non-proliferation. The European Union and the 2005 NPT Review Conference" in Chaillot Paper, $\mathrm{n}^{\circ}$ 77, EU Institute for Security Studies, Paris, 2005; ZANDERS, J.P. and NIXDORFF, K., "Enforcing Non-Proliferation: The European Union and the 2006 BTWC Review Conference" in Chaillot Paper, $\mathrm{n}^{\circ}$ 93, EU Institute for Security Studies, Paris, 2006.

25 Vid. SMITH, K. E., "Speaking with One Voice? European Union Co-ordination on Human Rights Issues at the United Nations" in Journal of Common Market Studies, vol. 44(1), 2006, pp. 113-137. 


\section{Abandoning Multilateralism as Political Ideology}

The EU, being built on a profound multilateral edifice, is somehow bound to cherish multilateralism. The "multilateralism-as-an-end-in-itself" discourse has been widespread within the EU and to some degree still is. For some, multilateralism serves as an ideology according to which the qualities of multilateral institutions are a matter of belief or faith and, thus, beyond debate and critical examination. Multilateral institutions are seen as morally superior to other foreign policy strategies. Furthermore, multilateralism is seen as an end in itself for which reason the instrumental dimension is systematically downplayed. Being multilateral is what counts and even if nothing can be achieved, it remains imperative to keep the multilateral machinery in place. In some understandings multilateralism and the UN are synonymous. Still others conceive of multilateralism, characterized by inclusion, participation and legitimacy, as a kind of supra-national democracy ${ }^{26}$. Due to its global membership, only the UN is considered a genuine example of multilateralism. Interestingly, the authors of the European Commission's annual report seem to take this stance and they might have been transferred to the EEAS. The positive version has also been called globalism and adherents argue that global agreements should be prioritized even if the number of veto players implies almost a guarantee that no agreement is the likely outcome. The alternative, in terms of an agreement concluded by the, say, 14 most important states for e.g. global climate, is dismissed and accompanied by grave concerns about legitimacy. Similarly, plurilateral agreements are also dismissed because they are by their nature essentially exclusive.

\section{Conclusion and Perspectives}

Leaving formal legal-institutional issues behind, this article has focused on some of the important political challenges the EEAS is facing. While legal-institutional issues are important, it does not follow that other issue are unimportant. Some of the political challenges identified are home-grown (e.g. overcoming the ideological approach to multilateralism and the use of bilateral and unilateral strategies for multilateral ends), whereas others are genuine international issues (e.g. the reform of multilateral institutions). Many multilateral institutions were born during the Cold War bipolarity, yet seem to have to grow up under conditions of multipolarity.

26 Vid. COX, RW., "Multilateralism and World Order" in Review of International Studies, vol. 18(2), 1992, pp. 161-80. 
It is also clear from the review above that the political challenges the EEAS are facing are as wide-ranging as one might suspect when dealing with a global player. They span the entire politico-military-diplomatic field, essentially everything between non-proliferation, crises management and the promotion of human rights.

Moreover, the challenges cover a wider horizon than many diplomats from smaller member states are used to. Hence, existing priorities will necessarily have to be reconsidered and cultures of concern and engagements will be merged.

Finally, it is a promising and refreshing sign that the EEAS - differently from the CFSP and the ESDP/CSDP - is not called a policy. 